\title{
ACKNOWLEDGMENTS
}

We are indebted to specialists who reviewed individual chapters for errors of fact: Peter Bellinger (Collembola), Richard Allen (Ephemeroptera), Rosser Garrison (Odonata), Richard Baumann (Plecoptera), David Weissman (Orthoptera), Sigurd Szerlip (Heteroptera), Philip Adams (Neuroptera), John Doyen (Coleoptera), Vincent Resh (Trichoptera), Julian Donahue (Lepidoptera), Paul Arnaud (Diptera), Don Rohe (Siphonaptera), and Roy Snelling (Hymenoptera).

Many other specialists provided information or assisted by commenting on particular aspects of the text, including the following: George Buxton, John Chemsak, Michael Collins, Donald Denning, George Edmunds, Kenneth Hagen, Alan Hardy, Gentaro Imadaté, Dennis Kopp, Ronald McGinley, Woodrow Middlekauff, and Darwin Tiemann.

Betty Birdsall, Claudia Madison, and Elizabeth Randal read major portions of the manuscript for clarity of interpretation to non-biologists and consistency in grammar; and Arthur C. Smith reviewed a draft of the entire manuscript, making many useful suggestions regarding its content.

Line drawings accompanying the synopses of orders were prepared by Celeste Green (redrawn from Barker et al.,1977; Borror et al., 1976; Essig, 1942; and Hogue and Truxal, 1970).

Special acknowledgment is made to Liz, who helped JAP keep work in proper perspective, suffered through indescribably dreary tedium of written drafts, typing, proofreading, and corrections; she tolerated my exasperation with the discovery of each new error and the endless, delay-causing additions, and she helped me develop writing as well as other half-forgotten talents.

To all of these, the photographers listed below, and the many others who wittingly, willingly, or otherwise provided assistance with our education during the preparation of this book, we extend our grateful thanks. 
The illustrations are original drawings, although many were made with reference to published photographs or drawings. This was done often with modifications of detail to clarify recognition features and to obtain likeness of natural postures of living insects. Acknowledgment is offered collectively for the contribution made by the original figures.

\section{PHOTOGRAPH CREDITS}

R. A. Amold: $12 \mathrm{e}$

G. Ballmer: $6 \mathrm{f}, 6 \mathrm{~g}$, cover (lower left)

Norman Bean: 13b

Jean Bourassa: $7 \mathrm{~h}$

L.R. Brown: $9 \mathrm{~b}$

James Carey: 7f, $12 \mathrm{~d}$

Patrick Craig: 3c, 3d, 3h, 5c, 5d, $7 \mathrm{~d}, 9 \mathrm{~h}, 13 \mathrm{~h}, 15 \mathrm{f}$

H.V. Daly: $8 b, 9 c$

J.P. Donahue: $11 \mathrm{c}$

E.B. Edney: $1 \mathrm{~g}$

D.K. Faulkner: 5e

Don Frack: 8d, 9a

R.W. Garrison: $1 \mathrm{~b}$

John Hafemik: 13f, 13g, 15c

K.S. Hagen: $15 \mathrm{~d}$

C.L. Hogue: 1a, 1e, 1f, 1h, 2a, 2c, 2d, 2e, 2f, 2g, 3a, 3b, 3e, $3 \mathrm{f}, 4 \mathrm{c}, 4 \mathrm{~d}, 4 \mathrm{f}, 4 \mathrm{~g}, 5 \mathrm{a}, 5 \mathrm{~b}, 6 \mathrm{a}$, $6 \mathrm{~b}, 6 \mathrm{~d}, 6 \mathrm{e}, 7 \mathrm{~b}, 7 \mathrm{c}, 8 \mathrm{a}, 9 \mathrm{f}$, $10 \mathrm{~d}, 10 \mathrm{e}, 10 \mathrm{f}, 10 \mathrm{~g}, 10 \mathrm{~h}, 11 \mathrm{a}$,
$11 \mathrm{~b}, 11 \mathrm{~d}, 11 \mathrm{e}, 11 \mathrm{~g}, 11 \mathrm{~h}, 12 \mathrm{a}$, $12 \mathrm{~b}, 12 \mathrm{c}, 14 \mathrm{a}, 14 \mathrm{c}, 14 \mathrm{~d}, 14 \mathrm{e}$, $14 \mathrm{~h}, 15 \mathrm{~b}, 15 \mathrm{~g}, 16 \mathrm{c}, 16 \mathrm{~d}, 16 \mathrm{~g}$, $16 \mathrm{~h}$, cover (upper and lower right)

J. Hogue: $15 \mathrm{~h}$

F.T. Hovore: 13d, 14b, 14f, 15e

J. Levy and P. Bryant: 12c, 13e; and R. Vanderhof: $12 \mathrm{f}$

J. Levy and E. Ling: $12 \mathrm{~h}$

Los Angeles County Museum: $4 \mathrm{~b}, 5 \mathrm{~g}, 10 \mathrm{a}, 10 \mathrm{~b}$

R.W. Merritt: $6 c$

R.J. Pence: $8 \mathrm{~g}, 15 \mathrm{a}$

J.A. Powell: 1c, 2b, 2h, 4a, 4e, 4h, 5f, 6h, 7a, 7e, 7g, 8c, 8e, $8 \mathrm{f}, 8 \mathrm{~h}, 9 \mathrm{~d}, 9 \mathrm{e}, 9 \mathrm{~g}, 10 \mathrm{c}, 11 \mathrm{f}$, $12 \mathrm{~g}, 13 \mathrm{a}, 13 \mathrm{c}, 16 \mathrm{a}, 16 \mathrm{~b}$

Frank Skinner: cover (upper left)

Roy Snelling: 16e

S.L. Szerlip: 1d, 3g, 5h, $16 \mathrm{f}$

Darwin Tiemann: $14 \mathrm{~g}$

NOTE: Figures on text illustration pages and on color plates are not necessarily reproduced to the same scale, even within a set shown on one page. Readers should refer to the text where sizes of the insects are given in the species accounts. 